\title{
Surface adsorption technique for the treatment of textile wastewaters
}

\author{
Ibrahim B. MUHAMMAD \\ Department of pure and industrial chemistry, Bayero University, P. M. B. 3011, Kano, Nigeria. \\ Email:bashir_mbi@yahoo.com
}

\begin{abstract}
Surface adsorption technique has been employed for the treatment of textile wastewater by electrolyzing the effluent with a current of $4 \mathrm{~A}$ for 200 minutes. Reductions in color and $\mathrm{pH}$ variation of the effluent were monitored through absorbance and $\mathrm{pH}$ measurements throughout the process. Concentration levels of $\mathrm{Ni}^{2+}$ in the wastewater ranged between 271 to $280 \mathrm{mg} / \mathrm{l}$, having an average of $274.4 \mathrm{mg} / \mathrm{l}$, standard deviation of $\pm 4.449719 \mathrm{mg} / \mathrm{l}$ and a coefficient of variation of $1.621618 \mathrm{mg} / \mathrm{l}$. Whereas $\mathrm{Cr}^{3+}$ ion levels varied from 196 to $200 \mathrm{mg} / \mathrm{l}$ with an average of $197.6 \mathrm{mg} / \mathrm{l}$, standard deviation of $\pm 2.302173 \mathrm{mg} / \mathrm{l}$ and coefficient of variation of 1.165067. It was observed that $\mathrm{pH}$ adjustments were necessary for treated samples to be employed for domestic purposes.

(ㄷ) 2009 International Formulae Group. All rights reserved.
\end{abstract}

Key Words: Effluents Treatment, Nickel, Chromium, Surface adsorption

\section{INTRODUCTION}

By processing cotton and wool as well as synthetic fibers such as polyester, nylon, acrylic etc., the textile industry is still regarded as one of the largest industrial sectors. Water usage constitutes a major requirement especially within the scouring, bleaching, dyeing and finishing sectors of that industry.

Effluent or wastewater treatment has been receiving attention from researchers in order to provide an environment free from chemical hazards. Thus, wide ranges of methods and materials have been employed by different workers for the treatment of effluents (Susan, 1999). Belkevich et al. (1976) highlighted the role of peat in the decontamination of the environment based on its selective extraction of ions such as $\mathrm{Cu}^{2+}$, $\mathrm{Co}^{2+}, \mathrm{Zn}^{2+}$ and $\mathrm{Ni}^{2+}$ from sewage. Similarly, Bakalyil et al. (1999) made use of column chromatographic technique with maize peat as the stationary phase for the color removal of dye waters.
The physico-chemical and engineering properties of a composite textile sludge sample from the southern part of India have been studied by Balasubramanian et al. (2006) with the sole aim of reusing the sludge as building material. However, the sludge samples failed to meet the required strength for structural applications but rather for nonstructural materials such as flooring tiles, solid and pavement blocks, and bricks.

Martel et al. (1997) identified the source and identity of compounds that were inducing hepatic mixed function oxygenase activity in fish from a thermochemical pulp mill effluent.

In 2003, Navaraj showed that the metals strongly present in the electroplating effluent are chromium and nickel, which is being tested individually and collectively to assess its toxic nature. The synergetic toxicity intensity of these metals is much stronger than individual effect. The result is noticeable in feeding budget and respiratory physiology of the fish, Oreochromis mossambicus. All parameters of the feeding budget show a 
significant amount of the concerted effect of these metals. In general, the concentration levels of these metals and indeed their toxicity call for their removal from effluents before reuse for domestic purposes (Bernes and Wilson, 1983).

\section{MATERIALS AND METHODS Sampling}

Sampling is one of the most important aspects to consider during the analysis of water, for which adequate sampling procedures have to be adopted in order to obtain any meaningful result for any constituent of a given sample (Kratochvil and Taylor, 1981). Five different textile effluent samples were collected at the point of discharge from a Textile factory at Bompai Industrial area of Kano state during different periods of production, and the samples were lettered $\mathrm{A}-\mathrm{E}$.

\section{Qualitative analysis}

Qualitative tests were carried out on all the samples (fresh and treated effluents alike) in order to ascertain the presence of the suspected metal ions according to Vogel (1987).

\section{Surface adsorption technique}

An electrolytic cell having a $2 \times 2 \mathrm{~cm}^{2}$ platinum foil electrode was used to electrolysed $100 \mathrm{~cm}^{3}$ samples of the effluent on passing $4 \mathrm{~A}$ for a period of 200 minutes, and the weight variation of the electrodes due to surface adsorption is used in estimating the amount of the respective metal ion in the sample.

\section{Absorbance measurement \\ The absorbance of the fresh effluent samples were determined immediately after sampling for their respective maximum wavelengths $\lambda_{\max }$. Further absorbance measurements were made after every 20 minutes during the course of the surface adsorption process using a Jenway 6051 Colorimeter.}

\section{pH measurements}

The $\mathrm{pH}$ of each effluent was measured concurrently as the adsorption process is taking place using a digital Jenway $3320 \mathrm{pH}$ meter after it has been standardized or calibrated.

\section{RESULTS AND DISCUSSION}

Most studies from the textile industries (ISPCH, 1995) have revealed that the most common unit operations employed in the textile wastewater treatment involves pretreatment for removal of inorganic solids and floating materials, flow equalization and neutralization, chemical coagulation, clarification, and biological treatment.

At maximum wavelength, $\lambda_{\max }$ equal to $520 \mathrm{~nm}$ the absorbance of the various effluent samples were measured (light green to dark green). Table 1 shows the results of the qualitative tests of the effluents from which can be shown the presence of $\mathrm{Ni}^{2+}$ in sample $\mathrm{A}$ and $\mathrm{Cr}^{3+}$ in sample $\mathrm{C}$. The presence of $\mathrm{Cl}^{-}$ ion was observed in all the samples that were analyzed; this is believed to be as a result of bleaching of the fabric prior to dyeing. However, other suspected metallic ions were not found. The presence of the metallic ions was believed to be as a result of using reactive dyes in the dyeing process. The concentration levels of the detected metallic ions from the effluent were found to have exceeded the applicable level of discharge from treatment plants as highlighted by Besselievre and Schwartz (1976). Comparatively, from figure 1 the concentration levels of these ions in the effluent varies in the order $\mathrm{Ni}^{2+}>\mathrm{Cr}^{3+}$, with $\mathrm{Ni}^{2+}$ concentrations ranging from a minimum of $271 \mathrm{mg} / \mathrm{l}$ to $280 \mathrm{mg} / \mathrm{l}$ having a mean of $274.4 \mathrm{mg} / \mathrm{l}$ and a standard deviation of $\pm 4.449719 \mathrm{mg} / \mathrm{l}$. Whereas $\mathrm{Cr}^{3+}$ concentration ranged from $194 \mathrm{mg} / \mathrm{l}$ to $200 \mathrm{mg} / \mathrm{l}$, having a mean value of $197.6 \mathrm{mg} / \mathrm{l}$ and a standard deviation of $\pm 2.302173 \mathrm{mg} / \mathrm{l}$.

The zero absorbance of the effluents observed from figure 2 expresses the extent of color reduction during the course of the electrode process. This adds to the level of the efficiency of the employed technique in treating the effluent, in that other than removal of metallic ions, the color of the respective effluents are scrubbed down to zero absorbance as per the sensitivity of the instrument used.

Records (Figure 3 ) of the $\mathrm{pH}$ values for both fresh and treated effluent is indicative of the need for $\mathrm{pH}$ adjustment before the treated water could be employed for domestic purposes (WHO, 1994). 
Table 1: Qualitative test for the suspected ions prior to the treatment.

\begin{tabular}{lcccc}
\hline Samples & \multicolumn{4}{c}{ Suspected Ions } \\
\hline & $\mathrm{Ni}^{2+}$ & $\mathrm{Pb}^{2+}$ & $\mathrm{Cr}^{3+}$ & $\mathrm{Cl}^{-}$ \\
A & + & - & - & + \\
B & - & - & - & + \\
C & - & - & + & + \\
D & - & - & - & + \\
E & - & - & - & + \\
\hline N.B.: $(+)=$ The indicated ion is present, $(-)=$ The indicated ion is absent.
\end{tabular}

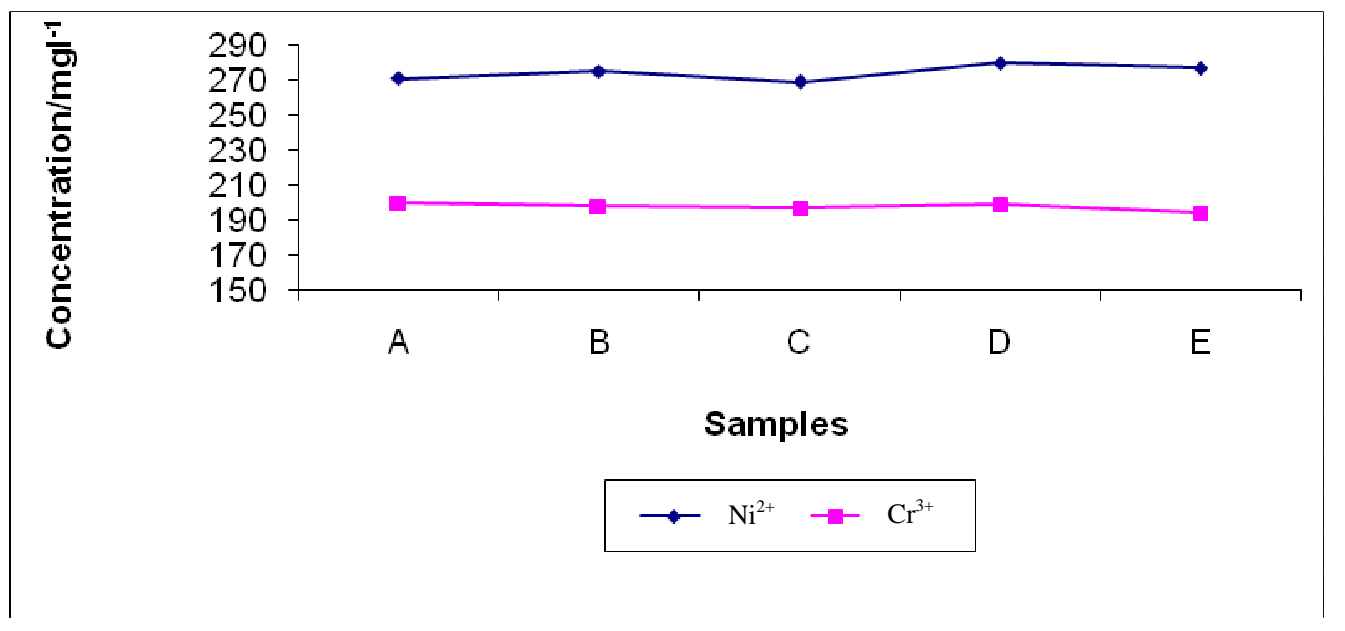

Figure 1: Concentration levels of $\mathrm{Ni}^{2+}$ and $\mathrm{Cr}^{3+}$ in various samples analyzed.

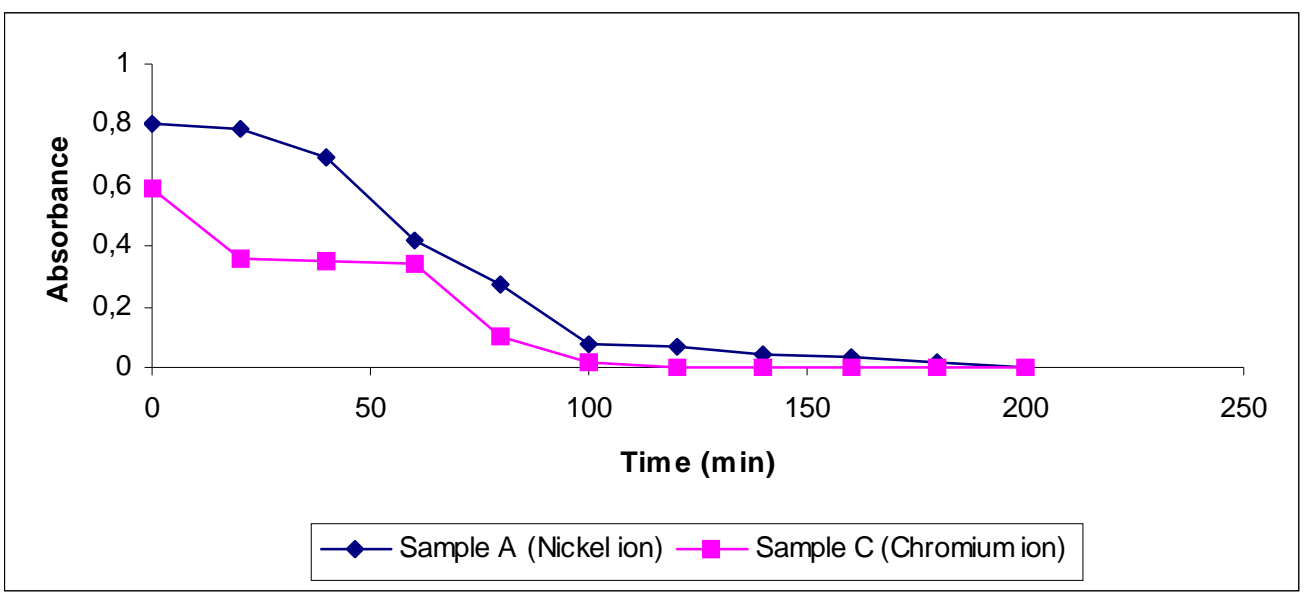

Figure 2: Level of color removal for the respective samples. 


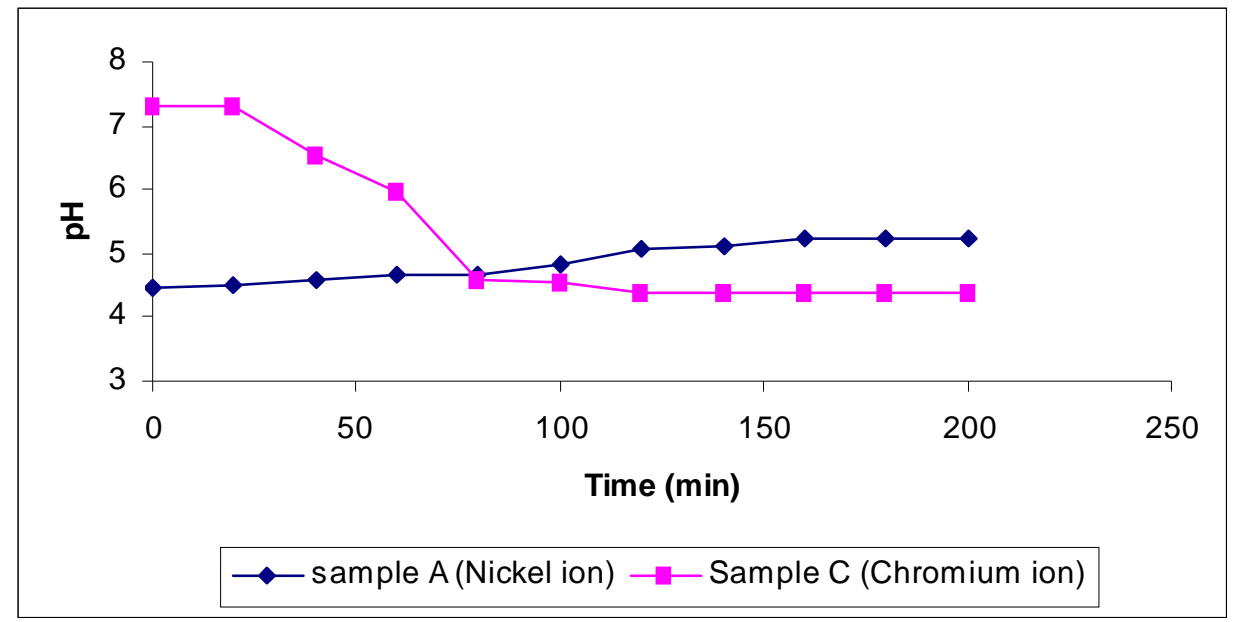

Figure 3: Variation of $\mathrm{pH}$ with time.

\section{Conclusion}

Textile effluents cause a high environmental impact when released into the environment without correct treatment (Kunz et al., 2001). In this work, the possibility of effluent treatment using surface adsorption has been highlighted with significant reduction in both the level of detectable ions and color of the effluent. However, for a larger scale treatment, volume of the effluent treated as a function of time, electrode size and amount of current supplied should be looked into in view of optimizing the efficiency of the technique.

\section{REFERENCES}

Bakalyil BA, Ibrahim MB, Ekanem EJ. 1999. Evaluation of maize cob peat for decolouration of dye waters. Nig. J. Chem. Res., 4: 63-67.

Balasubramanian J, Sabumon PC, Lazar John, U, Ilangovan R. 2006. Reuse of textile effluent treatment plant sludge in building materials. Waste manag., 26(1): 22-28.

Barnes D, Wilson F. 1983. Chemistry and Unit Operation in Water Treatment. Applied Science Publishers: London; 268.

Belkevich PI, Gaiduk KA, Chistora LR. 1976. The role of peat in the decontamination of environment. Proc. Int. Peat Congr., 1: 328-48.
Besselievre EB, Schwartz M. 1976. The Treatment of Industrial Wastes. (2nd edn). McGraw - Hill: New York; 247.

ISPCH (Industrial Safety and Pollution Control Handbook). 1995. A joint publication of National Safety Council and Associate (Data) Publishers Pvt. Ltd., Hyderabad, (2nd edn). 2nd reprint; 451466.

Kratochvil B, Taylor JK. 1981. Sampling for chemical analysis. Anal. Chem., 53: 924A-938A.

Kunz A, Reginatto V, Duran N. 2001. Combined treatment of textile effluent using sequence phanerochaete chrysosporium-ozone. Chemosphere, 44(2): 281287.

Martel PH, Kovacs TG, O'Connor BI, Voss RH. 1997. Environ. Toxicol. Chem., 16(11): 2375 - 2383.

Navaraj PS. 2003. Synergetic effect of metals of electroplating industry effluent on physiology of the fish, Oreochromis mossambicus. Proc. J. Phys., 107: 925.

Susan DR. 1999. Water Analysis. Anal. Chem., 71(12): 181R -215R.

Vogel AI. 1987. Qualitative Inorganic Analysis, Revised by G. S. Vehla, (6th edn); 174: 113-121.

WHO (World Health Organisation). 1994. Guidelines for Drinking Water Quality, 2:109, Health Criteria and Supporting Information, Belgium. 